\title{
Evaluation of fucoidan from Sargassum duplicatum on performance immune responses, serum biochemical, and hematological testing in
}

\section{rats}

\author{
Ellya Sinurat*, Endar Marraskuranto, Subaryono Subaryono \\ Research Center and Development for Marine and Fisheries Product Processing and Biotechnology, Jl. Petamburan VI, K.S. Tubun, Jakarta, Indonesia.
}

\begin{tabular}{|c|c|}
\hline ARTICLE INFO & ABSTRACT \\
\hline Received on: $25 / 11 / 2020$ & \multirow{4}{*}{$\begin{array}{l}\text { This study investigates the hematological and serum biochemical effects of the fucoidan to ascertain the safety } \\
\text { of fucoidan from Sargassum duplicatum. Fucoidan from } S \text {. duplicatum was extracted using water as a solvent } \\
\text { and precipitated with calcium chloride. The parameters of the fucoidan quality test included water content, total } \\
\text { carbohydrate, total sulfate, moisture content, and uronic acid. The extract was used for in vivo immunostimulant test } \\
\text { using Sprague Dawley rats for } 14 \text { days with four treatments. The experimental rats were fed with fucoidan solvent as } \\
\text { a control (P0) and fucoidan for the treatment at a dose of } 1(\mathrm{P} 1), 2(\mathrm{P} 2) \text {, and } 4 \mathrm{~g} / \mathrm{kg} \text { body weight }(\mathrm{BW})(\mathrm{P} 3) \text {. Serum } \\
\text { biochemical and hematological test parameters included liver function }[(\mathrm{serum} \text { glutamic-pyruvic transaminase }() \text { and } \\
\text { glutamic-oxoloacetic transaminase ()]), kidney function, red blood counts, and white blood differentials. The results } \\
\text { of the chemical composition of fucoidan show that it contains uronic acid of } 0.28 \% \text {, sulfate of } 11.2 \% \text {, moisture } \\
\text { content of } 8.25 \% \text {, and total polysaccharide of } 60.5 \% \pm 4.5 \% \text {. Immunostimulant activity results showed an increase } \\
\text { in macrophage activity in the fucoidan-treated rats but did not affect kidney function. In vivo immunostimulant test } \\
\text { results in white rats show that giving fucoidan } 1 \mathrm{~g} / \mathrm{kg} \mathrm{BW} \mathrm{can} \mathrm{increase} \mathrm{the} \mathrm{immune} \mathrm{system} \mathrm{two} \mathrm{times} \mathrm{higher.}\end{array}$} \\
\hline Accepted on: 26/02/2021 & \\
\hline Available online: $05 / 06 / 2021$ & \\
\hline $\begin{array}{l}\text { Key words: } \\
\text { Fucoidan, Sargassum } \\
\text { duplicatum, } \\
\text { immunomodulatory, } \\
\text { macrophages, Toxicity. }\end{array}$ & \\
\hline
\end{tabular}

\section{INTRODUCTION}

Fucoidan is a sulfated polysaccharide from brown algae and marine invertebrates (Klettner, 2016). It is a heteropolysaccharide that is mainly composed of fucose and sulfate esters. It also comprises other monosaccharides like galactose, glucose, mannose, rhamnose, arabinose, xylose, uronic acid, proteins, and acetyl groups (Wang et al., 2019). Based on its polysaccharide structure, fucoidan has immune stimulator potential. The main sugar component of fucoidan that has an immunomodulatory function is L-fucose. Because of that, it has been found to have various bioactivities, including antioxidant, anti-inflammatory, immunoregulatory (Sun et al., 2018; Zhang et al., 2015), antiviral, antitumor, antidiabetic, and antihepatic injury activities (Peng et al., 2019).

${ }^{*}$ Corresponding Author

Ellya Sinurat, Research Center and Development for Marine and Fisheries Product Processing and Biotechnology, Jl. Petamburan VI, K.S.Tubun, Jakarta,Indonesia.E-mail: ellya_sinurat@yahoo.com
Fucoidan's immunomodulatory activity is determined by several factors such as the type of extract, source algae, molecular weight, content, and other fucoidan components (Lee et al., 2019). The composition and structure of the fucoidan carbohydrate chain vary and are influenced by seaweed species as its source (Ale et al., 2011). Several studies have showed the ability of fucoidan extracted from several alga sources to induce the immunostimulant effect.

Teruya et al. (2010) reported that fucoidans isolated from Laminaria angustata var. Longissima stimulated the production of nitric oxide (NO), tumor necrosis factor- $\alpha(\mathrm{TNF}-\alpha)$, and interleukin-6 (IL-6) in RAW 264.7 cells. Jin and Yu (2015) also reported that fucoidan from Undaria pinnatifida induced IL-6, IL-8, and TNF- $\alpha$ production in human neutrophils via the phosphatidylinositol 3-kinase (PI3K)/protein kinase B (AKT) signaling pathway. Other studies have shown that fucoidans with lower molecular weight have a more significant effect on inducing an immune response (Jang et al., 2014). Other researchers showed fucoidan's ability to increase the immune response of Th1 and natural killers cells (Miyazaki et al., 2019). It involves several signaling pathways 
in macrophage activation; almost all of these signals are closely related to cytokine expression associated with inflammation and inducible nitric oxide synthase (iNOS). Several studies have shown that various polysaccharides can increase the transcription activity of iNOS by activating nuclear factor-kappa B, thus encouraging NO formation in macrophages (Kouakou et al., 2013; Park, 2014).

Brown seaweed Sargassum duplicatum are abundant in almost all Indonesian waters and can be obtained in a year. This study was conducted to evaluate the immunostimulatory activity of fucoidan extracts of $S$. duplicatum, expressed as macrophage NO production. The immunomodulatory improving effects of fucoidan compound agents were investigated using in vivo studies. The present research examined the effects of $S$. duplicatum fucoidan at high doses on hematological and serum biochemical to confirm the safety or ability of test animals to digest the fucoidan

\section{MATERIALS AND METHODS}

\section{Materials}

The brown seaweed $S$. duplicatum as the main raw material was collected from Binuangeun, Banten, Indonesia. The seaweed samples were collected by local fishermen from 0.5 to 10 m depth between July and August 2018.

\section{Experimental animals and housing conditions}

Male white Sprague Dawley rats were obtained from Laboratory of Animal Management Unit [Unit Pengelola Hewan Laboratorium (UPHL)], Faculty of Veterinary Medicine [Fakultas Kedokteran Hewan (FKH)], Bogor Agricultural University [Institut Pertanian Bogor (IPB)], Bogor, Indonesia, with a weight of $200-250 \mathrm{~g}$. The feed contains water $(13 \%)$, protein $(19 \%)$, fat $(21 \%)$, fiber $(5 \%)$, ash $(7 \%)$, calcium $(0.9 \%)$, phosphorus $(0.6 \%)$, and total energy of 3,000-3,100 kcal/g. Before testing the samples, the rats were acclimatized for 2 weeks to adapt to the animal enclosure environment. They were held in a 12-hour dark/ light cycle at $22^{\circ} \mathrm{C} \pm 3{ }^{\circ} \mathrm{C}$ and permitted free access to standard laboratory diets [(purchased from National Food and Drug Agency, Indonesia (BPOM)] and tap water ad libitum during the experiments. Male and female rats were obtained from BPOM for experiments $\mathrm{LD}_{50}$ and granted by the Animal Ethical Committee of Pharmacy Faculty, University of Indonesia.

\section{Extraction of fucoidan}

The fucoidan extract was obtained from defatted $S$. duplicatum. The defatted algae were prepared using the modified method of Sinurat and Rosmawaty (2015). The fucoidan was extracted from the defatted algal powder by soaking in $0.01 \mathrm{M}$ $\mathrm{HCl}$ of $\mathrm{pH} 4$ at the ratio of $1: 10(w / v)$ by stirring for 6 hours.

The resulting extract was then filtered using a 350-mesh nylon screen, added to $4 \mathrm{M} \mathrm{CaCl}_{2}$, left at room temperature for 30 minutes, and refiltered using a 500-mesh nylon screen. After diluting with distilled water until the final $\mathrm{CaCl}_{2}$ concentration of $2 \mathrm{M}$, the filtrate was centrifuged at $15,344 \mathrm{~g}$ for 15 minutes, then increased with $3 \mathrm{M} \mathrm{CaCl}_{2}$, and centrifuged at a speed of $15,344 \mathrm{~g}$ for 15 minutes. The sample's solubility was decreased by the addition of ethanol $(1: 2)$ and then left at room temperature overnight. The precipitated polysaccharides containing fucoidan were collected through centrifugation. The pellet formed was completely dried in spray drying. The fucoidan yield was estimated from the ratio of crude fucoidan weights to the defatted algal dry weight (Sinurat et al., 2016b). The whole process was carried out in triplicate, and the yield was mentioned as mean \pm standard deviation (SD). All yields were collected and then analyzed and the yield was stated as mean $\pm \mathrm{SD}$.

\section{Determination of chemical composition of crude fucoidan}

The total polysaccharides content of fucoidan was analyzed according to the method described by Dubois et al. (1956) using phenol- $\mathrm{H}_{2} \mathrm{SO}_{4}$ reagent and L-fucose (Sigma) as the standard. The sulfate content was measured using $\mathrm{K}_{2} \mathrm{SO}_{4}$ (Merck) as the standard based on the $\mathrm{BaCl}_{2}$-gelatin method. Fucoidan sample was hydrolyzed $(15 \mathrm{mg})$ in a solution of $3 \mathrm{M} \mathrm{HCl}$ for 17 hours at $100^{\circ} \mathrm{C}$ (Dodgson and Price, 1962). The content of uronic acid in fucoidan was analyzed by a carbazole--sulfuric acid-borate method using D-glucuronic acid (Sigma) as standard (Bitter and Muir, 1962). All yields were calculated from the dried weight of fucoidan and converted into a percentage. Absorbance measurements were recorded in triplicate using an Ultrospec 2,100 UV/visible spectrophotometer (Thermo Scientific).

\section{$\mathrm{LD}_{50}$ dose determination}

$\mathrm{LD}_{50}$ is the amount of material which causes death to $50 \%$ of the population. $\mathrm{LD}_{50}$ of the extract was analyzed according to Indonesian Food and Drug Authority or Indonesian FDA (BPOM) guidelines no. 7/2014. The test item was fed orally to one rat at a dose of $6.941 \mathrm{mg} / \mathrm{kg} /$ body weight (BW). Since the rat died within an hour after receiving the dose, a lower dose of $1 \mathrm{~g} / \mathrm{kg}$ was tested in another group of three rats to find $\mathrm{LD}_{50}$.

After dosing, rats' mortality was observed for up to 6 hours as a clinical sign of toxicity. Furthermore, it was recorded every day until 14 days when the animal was euthanized. This protocol was followed as per Committee for the Purpose of Control and Supervision of Experiments on Animals and approved by the Animal Ethical Committee of Pharmacy Faculty, University of Indonesia.

\section{Feeding experiment}

All animals were acclimatized for 2 weeks (14 days) before starting the experiment. Then, the experimental rats were divided into a randomized complete design with four treatments and seven replications. The experimental design pattern is presented in Table 1.

\section{Hematology and serum biochemistry studies}

After being acclimatized for 14 days, the rats had their blood drawn through vena coccygea to observe Red blood cell

Table 1. Experimental design for in vivo immunomodulatory test.

\begin{tabular}{llc}
\hline Group & Treatment & n (rat) \\
\hline $\begin{array}{l}\text { Fucoidan } \\
\text { control (P0) }\end{array}$ & Experimental mice were given fucoidan solvent as a control & 7 \\
Group 1 (P1) & Experimental mice were given fucoidan dose of 1 g/kg BW & 7 \\
Group 2 (P2) & Experimental mice were given fucoidan dose of 2 g/kg BW & 7 \\
Group 3 (P3) & Experimental mice were given fucoidan dose 4 g/kg BW & 7 \\
\hline
\end{tabular}


(RBC counts, hematocrit, and hemoglobin), white blood cells (WBC counts, neutrophils, lymphocytes, monocytes, basophils, and eosinophils), liver function [serum glutamic-pyruvic transaminase (SGPT) and glutamic-oxoloacetic transaminase (SGOT)], and kidney function (urea and creatinine). After blood sampling, the rats were treated according to the experimental design for 6 days.

After 7 days, rats were injected intraperitoneally with $2 \mathrm{ml}$ of Staphylococcus aureus bacterial suspension and left for 1 hour. Then, the rats were euthanized using a combination of ketamine and xylazine. Next, the stomachs of the rats waswere dissected using sterile tweezers and surgical scissors. Peritoneal fluid was taken using a micropipette. The peritoneal liquid was daubed on an object glass and fixed with methanol for 5 minutes, then stained with Giemsa staining, kept to stand for 20 minutes, and washed with running water. Then, the preparations were seen under a microscope to calculate the activity and capacity of macrophage phagocytosis. On day 8, we observed (RBC counts, hematocrit, and hemoglobin), (WBC counts, neutrophils, lymphocytes, monocytes, basophils, and eosinophils), liver function (SGPT and SGOT), and kidney function (urea and creatinine).

The parameters observed consisted of phagocytic capacity of macrophages, (RBC counts, hematocrit, and hemoglobin), and (WBC counts, neutrophils, lymphocytes, monocytes, basophils, and eosinophils). Hemocytometer was used as a tool for calculating the number of WBC using WBC fluid. The level in the leukocyte count was counted from a different type of WBC from the Giemsa-colored slides from each of the 30 oil fields immersed for microscopy purposes (Coles, 1974); liver function (SGPT and SGOT) and SGOT and SGPT enzymes were analyzed using the kit package (Pars Azmoon Co; Tehran, Iran) (Toghyani et al., 2011); and kidney function (ureum and urea creatinine) levels were analyzed using a photoelectric colorimeter.

\section{Histopathological examination}

Pathological changes were observed according to Raghuramulu et al. (2003). All the histopathological changes prior to seaweed water extract were observed according to Ganesan et al. (2019). All the rats divided into four groups, P1, P2, P3, and the control $(\mathrm{K})$, were sacrificed 24 hours after their respective daily doses (Table 1). The liver and kidney were examined according to Ajibade et al. (2012).

\section{Statistical analysis}

All the tests were carried out independently in triplicate. Data were processed using the Statistical Package for the Social Sciences 19.0 software (IBM Corporation, Armonk, NY).

\section{RESULTS AND DISCUSSION}

\section{Characterization extract fucoidan}

Seaweed used as raw material for fucoidan extraction was brown seaweed $S$. duplicatum which grows at a depth of $0.5-$ $10 \mathrm{~m}$. Brown seaweed is attached to the substrate bottom of the water. The length of the brown seaweed thallus was around 30-100 $\mathrm{cm}$. This process produced a fucoidan crude extract at amounts of $4.32 \% \pm 0.40 \%$ (seaweed DW). The chemical compositions of fucoidan were $0.28 \%$ of uronic acid, $11.2 \%$ of sulfate, $8.25 \%$ of moisture content, and $60.5 \%$ of total polysaccharide.

\section{Toxicity test $\mathbf{L D}_{50}$}

Based on the results of the acute toxicity test using male mice and female mice using BPOM method No. 7 in 2014, the results showed that $\mathrm{LD}_{50}$ for female mice and male mice was the same at $6.941 \mathrm{~g} / \mathrm{kg} \mathrm{BW}$. At this concentration, the mice died; an autopsy was conducted on the organs of the mice. The results showed that there are no differences in the size and shape of vital organs. These results of $\mathrm{LD}_{50}$ showed that fucoidan extract was declared nontoxic. From these results, there was no serious toxic effect on the male and female rats that were given fucoidan orally up to $6.941 \mathrm{~g} / \mathrm{kg} \mathrm{BW}$. The highest dosage tested in this study was $4 \mathrm{~g} / \mathrm{kg}$ BW and therefore may be safe for clinical use. A previous study showed that fucoidan derived from Laminaria japonica did not cause a significant toxicological effect on Wistar rats that were given $300 \mathrm{mg} / \mathrm{kg} \mathrm{BW} /$ day for 6 months. Although there were prolonged clotting times at the administration of 900 and $1,500 \mathrm{mg} / \mathrm{kg} \mathrm{BW} /$ day, it showed that fucoidan from $L$. japonica had no negative effect at $300 \mathrm{mg} / \mathrm{kg} \mathrm{BW} /$ day (Ning et al., 2005). The same result also showed that fucoidan from Cladosiphon okamuranus was considered nontoxic in rats after oral administration for 3 months up to $600 \mathrm{mg} / \mathrm{kg}$ BW per day (Gideon and Rengasamy, 2008). Although there were slight differences between the experimental designs and settings in the studies, these results, including ours, suggested that the potential toxicity of fucoidan could be different from various sources and may require confirmation individually to maximize biological efficiency, while lowering any potentially harmful effects (Chung et al., 2010).

\section{Hematology}

Hematology parameters of rats before fucoidan treatment (in Table 2) show no significant differences in each hematological parameter value of rats' blood in all groups before the treatment ( $p$ $<0.05)$. Hematology parameters of rats after fucoidan treatment are shown in Table 3. We added two new parameters, that isi.e., the number of macrophages and macrophage activity. From these parameters, we want to know the effect of fucoidan treatment on the rats' blood.

Staphylococcus aureus is a pathogen bacteria responsible for the majority of human skin and soft tissue infections, including cellulitis, impetigo, folliculitis, ulcers infectious, and wounds. It can also cause invasive and life-threatening infections, such as pneumonia, meningitis, bacteremia, abscesses, endocarditis, osteomyelitis, and sepsis (Miller and Cho, 2011).

In this study, $S$. aureus has been shown to stimulate immune functions and this was indicated by increasing the levels of WBC. The WBC profiles showed that it increased after the administration of fucoidan. The increase in WBC might indicate the activation of the defense and immune system of the body and shows that there are edema and inflammation in the tissues (Mongi et al., 2011; Yousef et al., 2003). The percentage of neutrophils in the treated rats was higher than that in the untreated rats. Neutrophils, the major population of circulating leukocytes, played a vital role in the defense against bacterial and fungal infections. Mature neutrophils have the shortest half-life compared to other leukocytes when serving constitutive apoptosis (Jin and Yu, 2015) The rising number of macrophages and macrophage activity 
Table 2. Hematology parameters of rats at before treated orally fucoidan extracts of S. duplicatum.

\begin{tabular}{lcccc}
\hline & \multicolumn{3}{c}{ Rats group } \\
\cline { 2 - 5 } & P0 & P1 & P2 & P3 \\
\hline RBC $\left(10^{6} / \mathrm{mm}^{3}\right)$ & $7.84 \pm 0.33^{\mathrm{a}}$ & $7.60 \pm 0.33^{\mathrm{a}}$ & $7.48 \pm 0.40^{\mathrm{a}}$ & $7.50 \pm 0.20^{\mathrm{a}}$ \\
Haematocrit (\%) & $44.53 \pm 1.35^{\mathrm{a}}$ & $42.81 \pm 1.68^{\mathrm{a}}$ & $42.30 \pm 2.06^{\mathrm{a}}$ & $42.39 \pm 0.95^{\mathrm{a}}$ \\
Hemoglobin (g/dl) & $15.70 \pm 0.58^{\mathrm{a}}$ & $15.15 \pm 0.62^{\mathrm{a}}$ & $14.99 \pm 0.74^{\mathrm{a}}$ & $14.97 \pm 0.40^{\mathrm{a}}$ \\
WBC $\left(10^{3} / \mathrm{mm}^{3}\right)$ & $12.49 \pm 1.29^{\mathrm{a}}$ & $13.01 \pm 0.90^{\mathrm{a}}$ & $12.53 \pm 0.71^{\mathrm{a}}$ & $12.88 \pm 0.59^{\mathrm{a}}$ \\
Lymphocytes (\%) & $73.46 \pm 7.25^{\mathrm{a}}$ & $73.88 \pm 3.50^{\mathrm{a}}$ & $74.13 \pm 2.31^{\mathrm{a}}$ & $74.13 \pm 2.10^{\mathrm{a}}$ \\
Monocytes (\%) & $7.71 \pm 2.67^{\mathrm{a}}$ & $8.91 \pm 2.74^{\mathrm{a}}$ & $9.20 \pm 1.11^{\mathrm{a}}$ & $9.00 \pm 1.00^{\mathrm{a}}$ \\
Neutrophils (\%) & $16.80 \pm 3.82^{\mathrm{a}}$ & $16.01 \pm 1.71^{\mathrm{a}}$ & $15.61 \pm 1.51^{\mathrm{a}}$ & $15.78 \pm 1.42^{\mathrm{a}}$ \\
Basophils (\%) & $0.13 \pm 0.10^{\mathrm{a}}$ & $0.23 \pm 0.11^{\mathrm{a}}$ & $0.23 \pm 0.10^{\mathrm{a}}$ & $0.25 \pm 0.05^{\mathrm{a}}$ \\
Eosinophils (\%) & $1.90 \pm 2.19^{\mathrm{a}}$ & $0.96 \pm 0.19^{\mathrm{a}}$ & $0.83 \pm 0.21^{\mathrm{a}}$ & $0.85 \pm 0.13^{\mathrm{a}}$ \\
\hline
\end{tabular}

Different letters in the same line show a real difference $(p<0.05)$.

Table 3. Hematology parameters of rats at post treated orally fucoidan extracts of S. duplicatum.

\begin{tabular}{|c|c|c|c|c|}
\hline & \multicolumn{4}{|c|}{ Rats group } \\
\hline & P0 & P1 & $\mathbf{P 2}$ & P3 \\
\hline $\mathrm{RBC}\left(10^{6} / \mathrm{mm}^{3}\right)$ & $7.44 \pm 1.06^{\mathrm{a}}$ & $7.73 \pm 0.22^{\mathrm{a}}$ & $7.60 \pm 0.47^{\mathrm{a}}$ & $7.18 \pm 0.46^{\mathrm{a}}$ \\
\hline Haematocrit (\%) & $41.444 .37^{\mathrm{a}}$ & $42.64 \pm 1.33^{\mathrm{a}}$ & $37.21 \pm 14.74^{\mathrm{a}}$ & $40.89 \pm 2.86^{\mathrm{a}}$ \\
\hline Hemoglobin (g/dl) & $13.87 \pm 1.51^{\mathrm{a}}$ & $15.03 \pm 0.45^{\mathrm{a}}$ & $15.10 \pm 0.89^{\mathrm{a}}$ & $14.50 \pm 1.06^{\mathrm{a}}$ \\
\hline $\operatorname{WBC}\left(10^{3} / \mathrm{mm}^{3}\right)$ & $12.51 \pm 1.74^{\mathrm{a}}$ & $12.53 \pm 1.26^{\mathrm{a}}$ & $13.53 \pm 1.53^{\mathrm{a}}$ & $13.36 \pm 0.83^{\mathrm{a}}$ \\
\hline Lymphocytes (\%) & $70.495 .33^{\mathrm{a}}$ & $73.08 \pm 6.68^{\mathrm{a}}$ & $72.70 \pm 5.36^{\mathrm{a}}$ & $69.14 \pm 6.95^{\mathrm{a}}$ \\
\hline Monocytes (\%) & $6.50 \pm 2.41^{\mathrm{a}}$ & $4.76 \pm 1.57^{\mathrm{a}}$ & $6.53 \pm 3.02^{\mathrm{a}}$ & $7.10 \pm 4.02^{\mathrm{a}}$ \\
\hline Neutrophils (\%) & $21.83 \pm 5.95^{\mathrm{a}}$ & $21.22 \pm 5.84^{\mathrm{a}}$ & $19.03 \pm 3.31^{\mathrm{a}}$ & $22.01 \pm 5.14^{\mathrm{a}}$ \\
\hline Basophils (\%) & $0.11 \pm 0.07^{\mathrm{a}}$ & $0.12 \pm 0.11^{\mathrm{a}}$ & $0.13 \pm 0.08^{\mathrm{a}}$ & $0.03 \pm 0.04^{\mathrm{a}}$ \\
\hline Eosinophils (\%) & $1.070 .54^{\mathrm{a}}$ & $0.81 \pm 0.31^{\mathrm{a}}$ & $1.61 \pm 1.60^{\mathrm{a}}$ & $1.73 \pm 1.43^{\mathrm{a}}$ \\
\hline $\begin{array}{l}\text { The number of } \\
\text { macrophages in } 100 \text { cells }\end{array}$ & $26.28 \pm 3.04^{\mathrm{d}}$ & $36.29 \pm 3.98^{c}$ & $59.43 \pm 8.07^{\mathrm{a}}$ & $48.14 \pm 6.97^{\mathrm{ab}}$ \\
\hline Macrophage activity & $23.43 \pm 4.58^{\mathrm{c}}$ & $43.29 \pm 10.00^{b}$ & $66.14 \pm 13.45^{\mathrm{a}}$ & $56.57 \pm 19.31^{\mathrm{ab}}$ \\
\hline
\end{tabular}

Different letters in the same line show a real difference $(p<0.05)$.

showed the influence of the fucoidan administration. The profiles also showed that there is an optimal concentration for fucoidan administration, that isi.e., the P2 group or the dose of $2 \mathrm{~g} / \mathrm{kg} \mathrm{BW}$. A macrophage is one indicator of the increasing endurance of living things. The higher the number of macrophages, the stronger the body, being able to fight viruses or bacteria that enter the body.

In Table 3, there are no significant differences between each rat group in $\mathrm{RBC}$, hematocrit, $\mathrm{Hb}$, WBC, lymphocytes, monocytes, neutrophils, basophils, and eosinophils values $(p<$ 0.05); however, while there are significant differences between each rat group in the number of macrophages and macrophage activity values $(p<0.05)$. Both parameter values increased as the dose of fucoidan extract increased. The results show that the number of macrophages is higher in the P1 treatment group than that in the control group (P0). The same results are also shown in the P2 and P3 groups. However, the number of macrophages in the $\mathrm{P} 2$ group is higher than that in the P3 group. We assume that there is optimum fucoidan concentration that can increase the number of macrophages and macrophage activity values.

According to the hematology profile, the macrophage activity value in the $\mathrm{P} 0$ group shows $23.43 \pm 4.58$, whereas in the P1 group (dose $1 \mathrm{gr} / \mathrm{kg} \mathrm{BW}$ ), it shows an increase of almost two times. In the P2 group (dose $2 \mathrm{~g} / \mathrm{kg} \mathrm{BW}$ ), the increase is three times higher than that in the control group, while the macrophage activity in the P3 group (dose $4 \mathrm{~g} / \mathrm{kg} \mathrm{BW}$ ) decreases but remains above that of the control group. The same trend was also shown in the number of macrophage profiles.

Macrophages, innate immune cells, play a leading role in the elimination of hazardous foreign substances as well as cancer cells (Guiducci et al., 2005), infectious pathogens (Kar et al., 2011), and waste cells (Feng et al., 2015). In the human immune system, macrophages are the first cells that identify foreign bodies' attack and rapidly become activated macrophages. The activated macrophages will lead to the innate immune responses and destroy the foreign bodies directly by phagocytosis and discharge of NO. Inducible iNOS produces NO and facilitates varied immune functions such as reducing the proliferation of pathogens and destroying pathogens (Aktan, 2004). iNOS is an important inflammatory gene whose transcription process is regulated by nuclear factor-kappa $\mathrm{B}(\mathrm{NF}-\kappa \mathrm{B})$. It is known that there are more than 400 stimuli that can activate $N F-\kappa B$ as a unit of pleiotropic transcription factors. NF- $\kappa \mathrm{B}$ is an important transcription factor that regulates inflammatory response and the body's immune system response. NF- $\kappa \mathrm{B}$ generally plays a role in controlling immune and inflammatory responses, cell proliferation, and apoptosis and regulating the transcription of 
various proinflammatory genes. Fucoidan, as $\beta$-glucans, has the potential to stimulate innate immune cells and encourage protective Thl immune responses in tumor-bearing rats (Qi et al., 2015). The biological activities of a macromolecule such as polysaccharides are significantly affected by their structures such as monosaccharide composition, molecular weight, glycosidic linkage forms, and triple-helix structure. Preceding research showed that higher molecular weight polysaccharides (MW 57,500 Da) derived from Asparagus officinalis had significant antioxidant and antitumor activities than that the lower (MW $51,100 \mathrm{Da}$ ) (Zhao et al., 2012). Fucoidan extract used in this study has high molecular weight polysaccharide estimated above 75,000 Da (Sinurat et al., 2016a).

\section{Serum biochemistry}

Serum biochemistry parameters of rats before extract treatment wereare presented in Table 4 and serum biochemistry parameters of rats after extract treatment wereare presented in Table 5. There are no significant differences in each biochemical parameter value between the rat groups before the treatment $(p<0.05$; Table 4). There are also no significant differences in each biochemical parameter value between rat groups after the treatment ( $p<0.05$; Table 5). However, the SGOT value increased in each rat group after the treatment.

(SGOT and SGPT enzymes are a precise indicator of serious liver cell impairment and pathological indicator of liver dysfunction. Severe damage to liver function will cause the release

Table 4. Serum biochemical parameters at before treated orally fucoidan extract of S. duplicatum.

\begin{tabular}{lcccc}
\hline & \multicolumn{3}{c}{ Rats Group } \\
\cline { 2 - 5 } & P0 & P1 & P2 & P3 \\
\hline SGPT (IU/l) & $42.11 \pm 20.03^{\mathrm{a}}$ & $33.75 \pm 4.67^{\mathrm{a}}$ & $37.16 \pm 5.36^{\mathrm{a}}$ & $37.02 \pm 3.06^{\mathrm{a}}$ \\
SGOT (IU/l) & $79.399 .86^{\mathrm{a}}$ & $82.06 \pm 10.68^{\mathrm{a}}$ & $82.86 \pm 6.61^{\mathrm{a}}$ & $81.46 \pm 4.59^{\mathrm{a}}$ \\
Ureum (mg/dl) & $16.88 \pm 5.14^{\mathrm{a}}$ & $15.96 \pm 3.16^{\mathrm{a}}$ & $16.88 \pm 2.63^{\mathrm{a}}$ & $17.90 \pm 2.03^{\mathrm{a}}$ \\
Creatinine (mg/dl) & $0.72 \pm 0.08^{\mathrm{a}}$ & $0.67 \pm 0.07^{\mathrm{a}}$ & $0.63 \pm 0.03^{\mathrm{a}}$ & $0.64 \pm 0.03^{\mathrm{a}}$ \\
\hline
\end{tabular}

Different letters in the same line show a real difference $(p<0.05)$.

Table 5. Serum biochemistry parameters at post treated orally fucoidan extract of $S$. duplicatum.

\begin{tabular}{lcccc}
\hline & \multicolumn{4}{c}{ Rats group } \\
\cline { 2 - 5 } & P0 & P1 & P2 & P3 \\
\hline SGPT (IU/l) & $44.17 \pm 13.39^{\mathrm{a}}$ & $30.53 \pm 4.51^{\mathrm{a}}$ & $30.53 \pm 3.10^{\mathrm{a}}$ & $45.34 \pm 27.95^{\mathrm{a}}$ \\
SGOT (IU/l) & $99.269 .50^{\mathrm{a}}$ & $92.20 \pm 7.62^{\mathrm{a}}$ & $94.53 \pm 25.59^{\mathrm{a}}$ & $93.30 \pm 4.88^{\mathrm{a}}$ \\
Ureum (mg/dl) & $20.67 \pm 2.41^{\mathrm{a}}$ & $20.57 \pm 1.68^{\mathrm{a}}$ & $16.75 \pm 1.81^{\mathrm{a}}$ & $17.00 \pm 2.06^{\mathrm{a}}$ \\
creatinine (mg/dl) & $0.80 \pm 0.13^{\mathrm{a}}$ & $0.83 \pm 0.15^{\mathrm{a}}$ & $0.69 \pm 0.08^{\mathrm{a}}$ & $0.75 \pm 0.10^{\mathrm{a}}$ \\
\hline
\end{tabular}

Different letters in the same line show a real difference $(p<0.05)$.

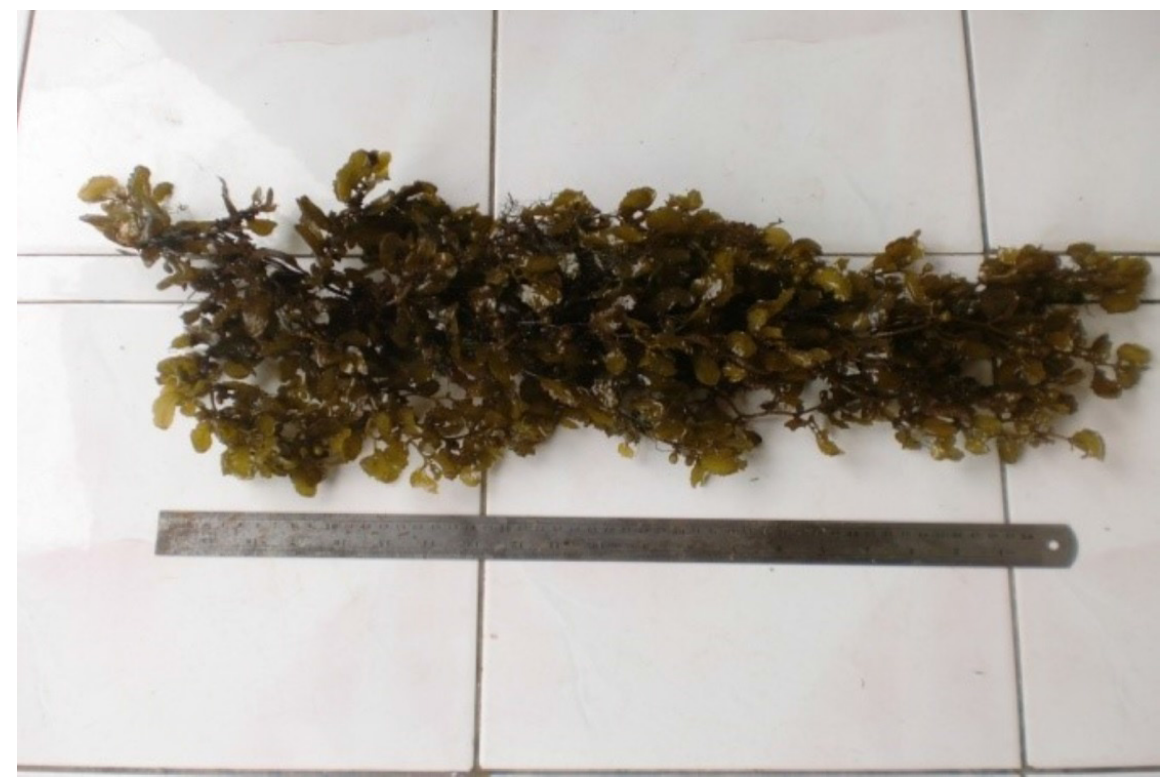

Figure 1. Brown seaweed Sargassum duplicatum. 

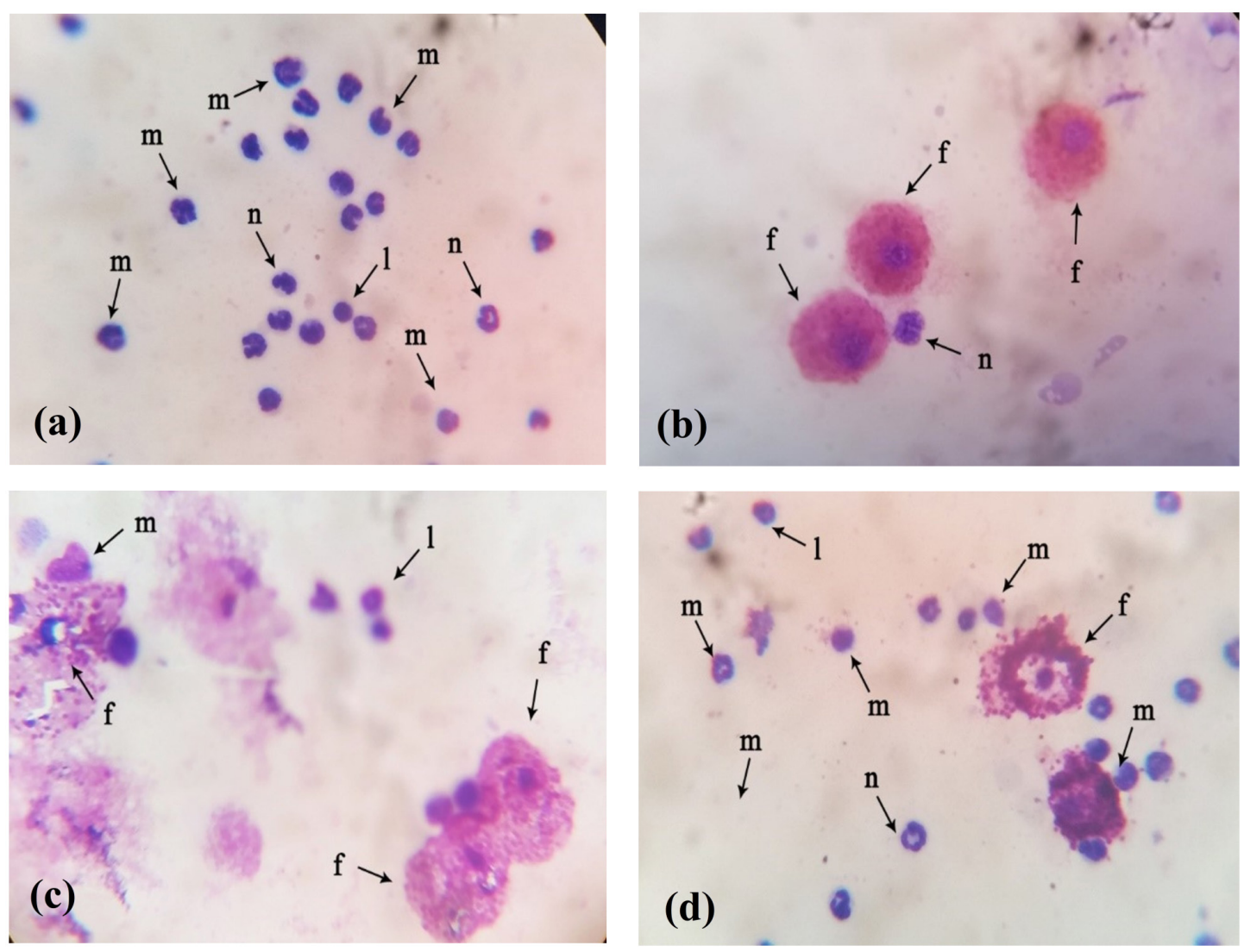

Figure 2. Histopathology blood cell of experimental rats after feeding with fucoidan extract (a) Control group-standard diet, (b) Fucoidan extract administrated rats, (c) Fucoidan extract administrated rats, (d) Fucoidan extract administrated rats.

of SGOT and SGPT from the liver cells into the bloodstream; thus, any abnormal enhancement in their concentration could suggest liver failure (Toghyani et al., 2011). The urea and creatinine blood concentration can indicate the function of the kidney. In this study, the level of SGOT and SGPT of the treated rats' group was not significantly different from the control group, and so was the level of urea and creatinine of the treated rat's' group. It can be considered that the fucoidan administration up to $4 \mathrm{~g} / \mathrm{kg} \mathrm{BW}$ did not have an adverse effect on rat liver and kidney. Blood cell histopathological performance was significantly different because fucoidan effectively weakened the inflammatory cytokines. In this study, fucoidan post-treatment until a dose of $4 \mathrm{~g} / \mathrm{kg} \mathrm{BW}$ did not damage the liver and kidney. Meanwhile, fucoidan treatment was found to be not toxic for the liver and kidney.

\section{Histopathology}

Histopathology results showed that there were visible blood clot stains in the rat blood cells of the fucoidan control group (Fig. 2). The stains appeared because of the $S$. aureus suspension administration to the experimental rats. On the contrary, the histopathology analysis appeared as blue and red stains that showed the effect of the fucoidan addition on the $S$. aureus infection in the remaining treatment groups, including Group 1 to Group 3. Such stains demonstrated the ability of fucoidan extract to destroy bacterial cells by phagocytosis so that bacterial cells are unable to damage other blood cells. Our result confirmed other results that showed the potential ability of fucoidan as antibacterial (Marudhupandi et al., 2013; Mohsin et al., 2016; Poveda-Castillo et al., 2018).

\section{CONCLUSION}

This study showed that fucoidan is nontoxic. In vivo immunostimulant test results also showed that the fucoidan administration starting from $1 \mathrm{~g} / \mathrm{kg} \mathrm{BW}$ can increase the immune system of rats almost two times higher than rats in the control group. However, we concluded that the optimum fucoidan administration is $2 \mathrm{~g} / \mathrm{kg}$ BW based on the increased number of macrophages and macrophage activity.

\section{AUTHORS' CONTRIBUTIONS}

ES designed the study and wrote the protocol as the main contributor. ES, EM, and SB interpreted the data, managed the analyses of the study. ES, EM and SB were the contributors to the analysis and interpretation of the data. All authors read and approved the final manuscript.

\section{ACKNOWLEDGEMENTS}

The authors acknowledge the research team at IPB Laboratory Management Unit (UPHL) Faculty of Veterinary Medicine, Bogor Agricultural University (FKH-IPB), Bogor, Indonesia for providing registered data. Contributors included: Dr. drh. Aulia, Dr. drh. Andriyanto, Msi and all staff laboratory. 


\section{CONFLICT OF INTEREST}

We declare that we have no conflict of interest.

\section{FUNDING}

There is no funding to report.

\section{CONFLICTS OF INTEREST}

The authors report no financial or any other conflicts of interest in this work.

\section{ETHICAL APPROVALS}

This study protocol was approved by Animal Ethical Committee of Pharmacy Faculty, University of Indonesia.

\section{PUBLISHER'S NOTE}

This journal remains neutral with regard to jurisdictional claims in published institutional affiliation.

\section{REFERENCES}

Ajibade TO, Olayemi FO, Arowolo ROA. The haematological and biochemical effects of methanol extract of the seeds of moringa oleifera in rats. J Med Plants Res, 2012; 6(4):615-21.

Aktan F. iNOS-mediated nitric oxide production and its regulation. Life Sci, 2004; 75(6):639-653.

Ale, MT, Mikkelsen JD, Meyer AS. Important determinants for fucoidan bioactivity: a critical review of structure-function relations and extraction methods for fucose-containing sulfated polysaccharides from brown seaweeds. Mar Drugs, 2011; 9(10):2106-2130.

Bitter T, Muir HM. A modified uronic acid carbazole reaction. Anal Biochem, 1962; 4(4):330-34.

Chung HJ, Jeun J, Houng SJ, Jun HJ, Kweon DK, Lee SJ. Toxicological evaluation of fucoidan from Undaria pinnatifida in vitro and in vivo. Phytother Res, 2010; 24(7):1078-83.

Coles EH. Veterinary clinical pathology. 2nd edition, WB Saunders, Philadelphia, PA, 1974.

Dodgson KS, Price RG. A note on the determination of the ester sulphate content of sulphated polysaccharides. Biochem J, 1962; 84:106-10.

Dubois M, Gilles KA, Hamilton JK, Rebers PA, Smith F. Colorimetric method for determination of sugar and related subtances. Anal Chem, 1956; 28(3):350-56.

Feng M, Chen JY, Weissman-Tsukamoto R, Volkmer JP, Ho PY, McKenna KM, Cheshier S, Zhang M, Guo N, Gip P, Mitra SS, Weissman IL. Macrophages eat cancer cells using their own calreticulin as a guide: roles of TLR and Btk. Proc Natl Acad Sci U S A 2015; 112(7):2145-50.

Ganesan AR, Subramani K, Balasubramanian B, Liud WC, Arasue MV, Al-Dhabie NA, Duraipandiyan Vu D. Evaluation of in vivo sub-chronic and heavy metal toxicity of under-exploited seaweeds for food application. J King Saud Univ Sci, 2019; 40:0-7.

Gideon PT, Rengasamy R. Toxicological evaluation of fucoidan from Cladosiphon okamuranus. J Med food, 2008; 11(4):638-42.

Guiducci C, Vicari AP, Sangaletti S, Trinchieri G, Colombo MP Redirecting in vivo elicited tumor infiltrating macrophages and dendritic cells towards tumor rejection. Cancer Res, 2005; 65(8):3437-47.

Jang JY, Moon SY, Joo HG. Differential effects of fucoidans with low and high molecular weight on the viability and function of spleen cells. Food Chem Toxicol, 2014; 68:234-38.

Jin JO, Yu Q. Fucoidan delays apoptosis and induces proinflammatory cytokine production in human neutrophils. Int $\mathrm{J}$ Biol Macromol, 2015; 73(1):65-71.

Kar S, Gunjan S, Das PK. Fucoidan cures infection with both antimony-susceptible and-resistant strains of leishmania donovani through Th1 response and macrophage-derived oxidants. J Antimicrob Chemother, 2011; 66(3):618-25.
Klettner A. Fucoidan as a potential therapeutic for major blinding diseases-a hypothesis. Mar Drugs, 2016; 14(31):1-13.

Kouakou K, Schepetkin IA, Yapi A, Kirpotina LN, Jutila MA, Quinn MT. Immunomodulatory activity of polysaccharides isolated from alchornea cordifolia. J Ethnopharmacol, 2013;146(1):232-42.

Lee HH, Cho YJ, Yu D, Chung D, Kim GH, Kang H, Cho H. Undaria Pinnatifida ucoidan-rich extract induces both innate and adaptive immune responses. Nat Prod Commun, 2019;14(8):1-8.

Marudhupandi T, Thipparamalai TAK. Antibacterial effect of fucoidan from Sargassum Wightii against the chosen human bacterial pathogens. Int Curr Pharm J, 2013; 2(10):156-58.

Miller LS, John SC. Immunity against Staphylococcus aureus cutaneous infections. Nat Rev Immunol, 2011; 11(8):505-18.

Miyazaki Y, Yuri I, Juneha B, Hayato N. Biochemical and biophysical research communications the cooperative induction of macrophage activation by fucoidan derived from Cladosiphon okamuranus and b-glucan derived from saccharomyces cerevisiae. Biochem Biophys Res Commun, 2019; 516(1):245-50.

Mohsin SRM, Sumayya A, Kurup GM. Bifunctional effect of fucoidan from padina tetrastromatica against human pathogenic microbes and free radicals. J Med Herbs Ethnomed, 2016; 2(2):1-10.

Mongi, S, Mahfoud M, Boumendjel A, Jamoussi K, Abdelfattah EF. Protective effects of vitamin $\mathrm{C}$ against haematological and biochemical toxicity induced by deltamethrin in male wistar rats. Ecotoxicol Environ Saf, 2011; 74(6):1765-69.

Ning L, Zhang Q, Song J. Toxicological evaluation of fucoidan extracted from Laminaria Japonica in wistar rats. Food Chem Toxicol, $2005 ; 43: 421-26$

Park HJ. Immune stimulatory activity of BRP-4, an acidic polysaccharide from an edible plant, Basella Rubra L. Asian Pac J Trop Med, 2014; 7(11):849-53.

Peng Y, Yuefan S, Wang Q, Hu Y, Yunhai H, Dandan R, Wu L, Liu $\mathrm{S}$, Cong $\mathrm{H}$, Zhou $\mathrm{H}$. In vitro and in vivo immunomodulatory effects of fucoidan compound agents. Int J Biol Macromol, 2019; 127:48-56.

Poveda-Castillo GDC, Dolores R, Martínez A, Pérez MP. Bioactivity of fucoidan as an antimicrobial agent in a new functional beverage. Beverages, 2018; 4(3):64.

Qi C, Yihua C, Lacey G, Chuanlin D, Bing L, Goetz K, Keqing Q, John V, Shinobu S, Yoichiro I, John R. Y, Jun Y. Differential pathways regulating innate and adaptive antitumor immune responses by particulate and soluble yeast-derived $\beta$-glucans. Blood J Am Soc Hematol, 2015; 117(25):6825-37.

Raghuramulu N, Madhavan Nair K, Kalyanasundaram S, National Institute of Nutrition (India). A manual of laboratory techniques. National Institute of Nutrition, Hyderabad, India, pp 56-8, 2003.

Ren Y, Guiqing Z, Lijun Y, Lingrong W, Chao L, Xiong F, Lin Z. Structural characterization and macrophage immunomodulatory activity of a polysaccharide isolated from Gracilaria Lemaneiformis. J Funct Foods, 2017; 33:286-96.

Sinurat E, Rosmawaty P. Evaluation of fucoidan bioactivity as anti-gastric ulcers in mice. Procedia Environ Sci Ictcred, 2015; 25:407-11.

Sinurat E, Saepudin E, Rosmawaty P, Hudiyono S. Characterization of fucoidan extracted from Sargassum polycystum different habitats. 5th International Conference on Earth Science and Environmental Engineering (ICESEE-16), 4(1), pp 2-5, $2016 \mathrm{a}$.

Sinurat E, Saepudin E, Rosmawaty P, Hudiyono S Immunostimulatory activity of brown seaweed-derived fucoidans at different molecular weights and purity levels towards white spot syndrome virus (WSSV) in shrimp Litopenaeus Vannamei. J Appl Pharm Sci, 2016b; 6(10):082-91.

Sun Y, Gong G, Guo Y, Wang Z, Song S, Zhu B, Zhao L, Jiang J. Purification, structural features and immunostimulatory activity of novel polysaccharides from Caulerpa Lentillifera. Int J Biol Macromol, 2018; 108:314-23. 
Teruya T, Shinji T, Yukihiro T, Masakuni T. Fucoidan isolated from Laminaria angustata Var. Longissima induced macrophage activation. Biosci Biotechnol Biochem, 2010; 74(9):1960-62.

Toghyani M, Majid T, Abbasali G. Evaluation of cinnamon and garlic as antibiotic growth promoter substitutions on performance, immune responses, serum biochemical and haematological parameters in broiler chicks. Livest Sci, 2011; 138(1-3):167-73.

Wang Y, Xing M, Qi C, Ji Q, Liang H, Song S. Biological activities of fucoidan and the factors mediating its therapeutic effects: a review of recent studies. Mar Drugs, 2019; 17(3):1-18.

Yin M, Zhang Y, Li H. Advances in research on immunoregulation of macrophages by plant polysaccharides. Frontiers in immunology, 2019; 10(145): 1-19.

Yousef MI, Abdallah GA, Kamel KI. Effect of ascorbic acid and vitamin E supplementation on semen quality and biochemical parameters of male rabbits. Anim Reprod Sci, 2003; 76(1-2):99-111.
Zhang W, Tatsuya O, Qing Y, Jun OJ. Fucoidan from Macrocystis Pyrifera has powerful immune-modulatory effects compared to three other fucoidans. Mar Drugs, 2015; 13(3):1084-104.

Zhao Q, Bingxian X, Jun Y, Fangchun Z, Jie X, Lingyun Y. In vitro antioxidant and antitumor activities of polysaccharides extracted from Asparagus officinalis. Carbohydr Polym, 2012; 87(1):392-96.

How to cite this article:

Sinurat E, Marraskuranto E, Subaryono S. Evaluation of fucoidan from Sargassum duplicatum on performance immune responses, serum biochemical, and hematological testing in rats. J Appl Pharm Sci, 2021; 11(06):146-153. 